\title{
Evaluation of Diagnostic Agreement Among Cephalometric Measurements for Determining Incisor Position and Inclination
}

\author{
Evaluación de la Concordancia Diagnóstica entre Mediciones Cefalométricas \\ para la Determinación de la Posición e Inclinación de los Incisivos
}

\author{
Ileana Paolina Gómez-Medina¹; David Alejandro Aguilar-Pérez²; Gabriel Eduardo Colomé-Ruíz丶 \\ Iván Daniel Zúñiga-Herrera'; ${ }^{1}$ Mauricio Escoffié-Ramírez ${ }^{1}$; José Rubén Herrera-Atoche'; \\ Jacqueline Adelina Rodríguez-Chávez ${ }^{3}$ \& Fernando Javier Aguilar-Pérez ${ }^{1}$
}

GÓMEZ-MEDINA, I. P.; AGUILAR-PÉREZ, D. A.; COLOMÉ-RUÍZ, G. E.; ZÚÑIGA-HERRERA, I. D.; ESCOFFIÉRAMÍREZ, M.; HERRERA-ATOCHE, J. R.; RODRÍGUEZ-CHÁVEZ, J. A. \& AGUILAR-PÉREZ, F. J. Evaluation of diagnostic agreement among cephalometric measurements for determining incisor position and inclination. Int. J. Morphol., 38(5):13861391, 2020.

SUMMARY: The incisors are a key factor in dental occlusion and dentofacial aesthetics; therefore, the sagittal position and inclination of the incisors is a key parameter in diagnosis and orthodontic treatment planning. In some cases, the orthodontist will use more than one cephalometric analysis, and thus different results can be obtained. The aim of this study was to establish the diagnostic agreement among the different cephalometric measurements used to determine the anteroposterior position and the inclination of the incisors. Lateral cephalometric radiograms of patients between 18 and 59 years old were measured ( $\mathrm{n}=260$ ). Digital cephalometric measurements were made with Dolphin Imaging software, by a single calibrated operator. Here, a specific cephalometric analysis was designed in the software analysis editor. The results for each variable and each measurement were registered and compared. Fleiss's Kappa statistical tests, Cohen's Kappa, and Kendall's coefficient were used to determine the strength of agreement using the Minitab software. The results showed diagnostic strength agreement between slight and moderate among measurements of the same variable. This indicates that same diagnosis might not be obtained when using different approaches to measure the anteroposterior position and inclination of the incisors. It was concluded that there is a difference in the diagnosis between one measurement and another because the results showed slight or moderate strength of agreement. However, in some cases, better agreement was found when the measurements were compared as a function of the diagnostic response.

KEY WORDS: Cephalometry; Orthodontics; Diagnosis.

\section{INTRODUCTION}

Cephalometry is a method of morphological and descriptive diagnosis that provides relevant data about skeletal and dentoalveolar malocclusions (Devereux et al., 2011; Nielsen, 2011). Different authors have proposed various cephalometric measurements to establish the normal parameters of the anteroposterior position and the inclination of the incisors. Occasionally, conflicting results can be obtained with different methods leading to different diagnoses (Pereda, 2013; Zamora et al., 2013; Herreros del Pozo et al., 2017; Guerrero et al., 2018).

Cephalometry is routinely used during the complete orthodontic examination. It is used to diagnose and develop an individualized treatment plan (de Sena et al., 2016). Cephalometry has been constantly improved over the last 50 years. It offers morphological and descriptive diagnosis as well as clinical applications to monitor patient growth. This can help predict the outcomes of conventional and/or surgical treatment (Casado, 2002).

Cephalometry can differentiate between skeletal and dentoalveolar malocclusions. It highlights the spatial relationships of the craniomaxillofacial complex at a given moment and allows comparisons over time (Devereux et al.; Pittayapat et al., 2014). It studies the morphology of hard and soft structures present in the head; among the hard

\footnotetext{
${ }^{1}$ Especialización en Ortodoncia Universidad Autónoma de Yucatán, México.

${ }^{2}$ Maestría en Odontología Infantil, Universidad Autónoma de Yucatán, México.

${ }^{3}$ Departamento de Clínicas Odontológicas Integrales, Universidad de Guadalajara, México.
} 
GÓMEZ-MEDINA, I. P.; AGUILAR-PÉREZ, D. A.; COLOMÉ-RUÍZ, G. E.; ZÚÑIGA-HERRERA, I. D.; ESCOFFIÉ-RAMÍREZ, M.; HERRERA-A TOCHE, J. R.; RODRÍGUEZ-CHÁVEZ, J. A. \& AGUILAR-PÉREZ, F. J. Evaluation of diagnostic agreement among cephalometric measurements for determining incisor position and inclination. Int. J. Morphol., 38(5):1386-1391, 2020.

structures, there are the incisors, both upper and lower, of which position and inclination can be established according to their bone structures (Nielsen).

The incisors are a key factor in dental occlusion and dentofacial aesthetics; therefore, the sagittal position and inclination of the incisors is a fundamental parameter to obtain the diagnosis and orthodontic treatment plan, especially in dental extraction borderline cases (Gul-e-Erum \& Fida, 2008; Devereux et al.; Jabbal et al., 2016). When these positions and inclinations are excessive, they are usually accompanied by maxillary discrepancies that can affect dental arches.

There is some variability in the position of the incisors according to their bone bases, which may limit therapeutic biomechanics - especially for the lower incisors (Jabbal et $a l$.). There are several methods to measure the sagittal positions and the inclinations of the incisors on lateral cephalograms: The work of Steiner, Ricketts, McNamara, Tweed, Downs, Jarabak, and Riedel are analyzed here. This variability may be due to different causes associated with the cephalometry as well as the criteria used by each author to perform the cephalometric measurements (Naragond et al., 2012; Durão et al., 2013, 2015). Thus, the aim of this study was to determine the diagnostic agreement among various cephalometric techniques that are used to measure the anteroposterior position and the inclination of the incisors.

\section{MATERIAL AND METHOD}

This retrospective, observational, analytical, crosssectional study was carried out with prior approval by the Research Committee of the Faculty with registration number SISTPROY FODO-2017-0004. The sample size was determined based on a non-probabilistic method, a level of significance of $95 \%$, and a margin of error of $5 \%$. The final sample consisted of 260 lateral cephalograms of patients aged 18 to 59 years. Radiographs of patients with a complete medical history and complete permanent dentition were included. There were excluded poorly projected radiographs and those with overlapping of structures as well as those that did not project the scale rule. Radiographs of patients with any systemic disease or syndrome were also excluded.

Patient identification data such as medical history number, age, sex, date of birth, date of the lateral radiograph, as well as lateral cephalograms were obtained from the clinical history of the postgraduate Clinic of Orthodontics.
The radiographs included were taken in the Radiology Department of the School of Dentistry using the Orthoceph ${ }^{\circledR}$ OC200 D digital cephalometric radiography equipment (Instrumentarium Dental Inc., Charlotte, USA). Dolphin imaging digital cephalometry software was used to measure the variables of the study. The digital images were stored in a computer exclusively designated for the study.

The radiographs were subsequently digitally traced by a single operator previously calibrated (Kappa> 0.85). From each cephalogram, the result of the anteroposterior position and inclination of the upper and lower incisors were recorded according to each studied cephalometric measurement. Here, a specific cephalometric analysis was created within the Dolphin Imaging software (Dolphin Imaging Systems LLC, Chatsworth, USA) including only the cephalometric measurements to be evaluated. The cephalometric landmarks, measurements, values, and specific determinations of each variable are detailed in Table I.

The MINITAB software (Minitab, Inc., State College PA, USA) was used to perform Fleiss's Kappa and Cohen's Kappastatistical analyses to determine the strength of agreement between the different cephalometric analyzes. Kappa $(\mathrm{K})$ values for concordance are reported in general and for each diagnostic possibility (outcome). The strength of agreement for the Kappa values was established according to the valuation given by Landis \& Koch (1977) (Table II). The Kendall concordance coefficient was also calculated and reported.

\section{RESULTS}

Our cohort was $62.3 \%$ females $(n=162)$ and 37.7 $\%$ males $(\mathrm{n}=98)$. The strength of agreement was established among the results obtained from each analysis for each of the variables. These results show that fair agreement was obtained $(\mathrm{K}=0.21)$ for the anteroposterior position of the upper incisor. Moderate agreement was obtained $(\mathrm{K}=0.57)$ for the anteroposterior position of the inferior incisor. Fair agreement was obtained $(K=0.25)$ for the inclination of the upper incisor. Fair agreement was obtained $(\mathrm{K}=0.40)$ for the inclination of the lower incisor. Table III shows statistical analyses to determine the strength of the agreement.

Furthermore, the results of the cephalometric measurements were evaluated to determine the agreement in the diagnosis using Cohen's Kappa statistical test by comparing the results between each pair of measurements for each studied variable (Table IV). 
GÓMEZ-MEDINA, I. P.; AGUILAR-PÉREZ, D. A.; COLOMÉ-RUÍZ, G. E.; ZÚÑIGA-HERRERA, I. D.; ESCOFFIÉ-RAMÍREZ, M.; HERRERA-A TOCHE, J. R.; RODRÍGUEZ-CHÁVEZ, J. A. \& AGUILAR-PÉREZ, F. J. Evaluation of diagnostic agreement among cephalometric measurements for determining incisor position and inclination. Int. J. Morphol., 38(5):1386-1391, 2020.

Table I. Cephalometric measurements included in the study.

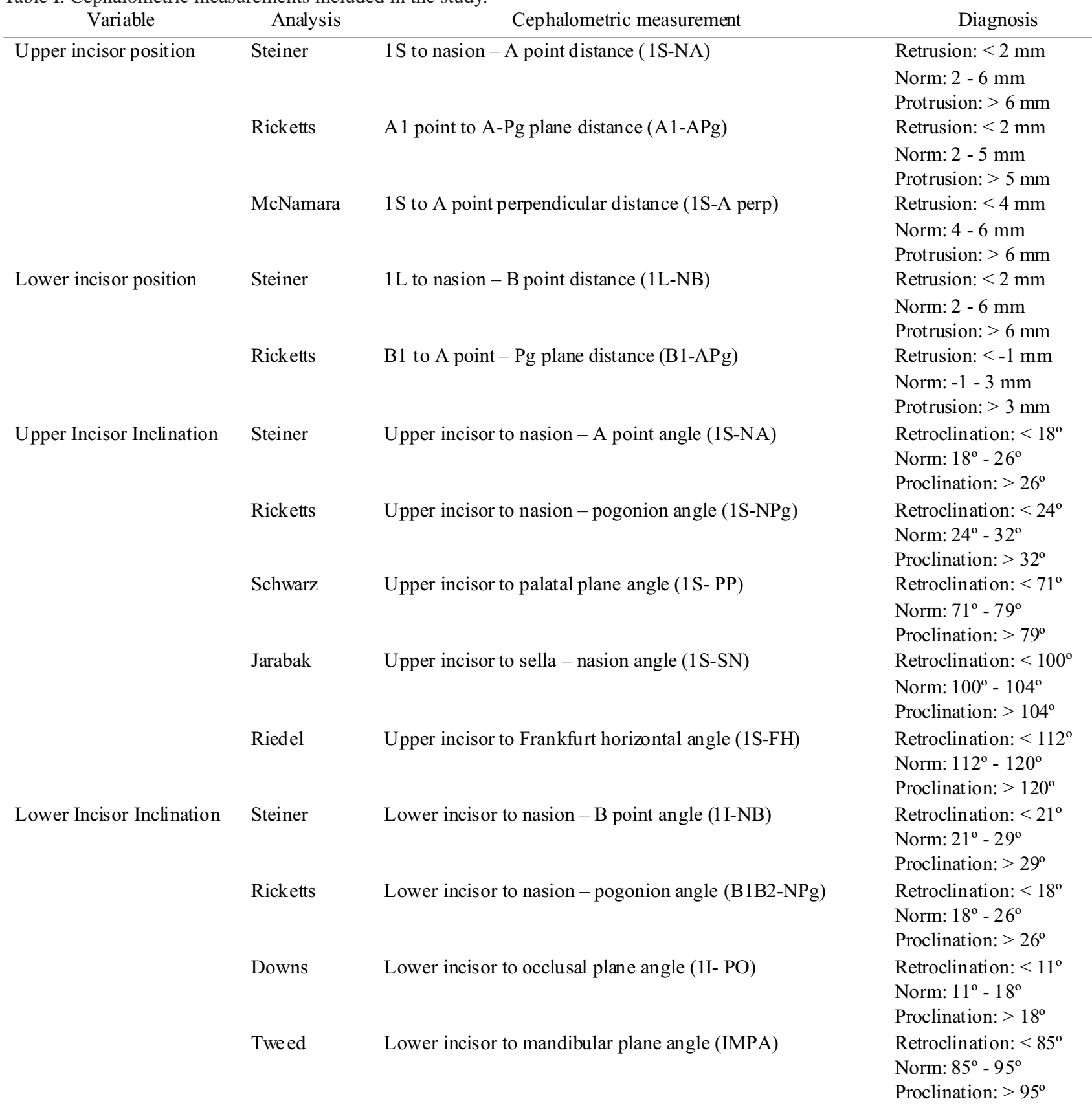

Table II. Strength of agreement according to the Kappa values.

\begin{tabular}{cl}
\hline Kappa values & Strength of agreement \\
\hline$<0.00$ & Poor \\
$0.01-0.20$ & Slight \\
$0.21-0.40$ & Fair \\
$0.41-0.60$ & Moderate \\
$0.61-0.80$ & Substantial \\
$0.81-1.00$ & Almost Perfect \\
\hline
\end{tabular}

\section{DISCUSSION}

The data show differences in diagnosis when different cephalometric analysis approaches are used. No report has yet evaluated the strength of agreement in the determination of the position and inclination of the incisors via different cephalometric measurements. There are reports of diagnostic agreement among the cephalometric analyses by different 
GÓMEZ-MEDINA, I. P.; AGUILAR-PÉREZ, D. A.; COLOMÉ-RUÍZ, G. E.; ZÚÑIGA-HERRERA, I. D.; ESCOFFIÉ-RAMÍREZ, M.; HERRERA-A TOCHE, J. R.; RODRÍGUEZ-CHÁVEZ, J. A. \& AGUILAR-PÉREZ, F. J. Evaluation of diagnostic agreement among cephalometric measurements for determining incisor position and inclination. Int. J. Morphol., 38(5):1386-1391, 2020.

Table III. Strength of agreement and Kendall coefficient of studied variables.

\begin{tabular}{|c|c|c|c|c|c|c|}
\hline Variable & Matches & Percentage & & Kappa & Agreement & Kendall \\
\hline \multirow[t]{4}{*}{ Upper incisor position } & 94 & $36.2 \%$ & Overall & 0.21 & Fair & 0.66 \\
\hline & & & Retrusion & 0.23 & Fair & \\
\hline & & & Norm & 0.15 & Slight & \\
\hline & & & Protrusion & 0.27 & Fair & \\
\hline \multirow[t]{4}{*}{ Lower incisor position } & 209 & $80.4 \%$ & Overall & 0.57 & Moderate & 0.82 \\
\hline & & & Retrusion & 0.36 & Fair & \\
\hline & & & Norm & 0.54 & Moderate & \\
\hline & & & Protrusion & 0.63 & Substantial & \\
\hline \multirow[t]{4}{*}{ Upper Incisor Inclination } & 54 & $20.8 \%$ & Overall & 0.25 & Fair & 0.63 \\
\hline & & & Retroclination & 0.47 & Moderate & \\
\hline & & & Norm & 0.03 & Slight & \\
\hline & & & Proclination & 0.30 & Fair & \\
\hline \multirow[t]{4}{*}{ Lower Incisor Inclination } & 112 & $43.1 \%$ & Overall & 0.40 & Fair & 0.70 \\
\hline & & & Retroclination & 0.36 & Fair & \\
\hline & & & Norm & 0.31 & Fair & \\
\hline & & & Proclination & 0.50 & Moderate & \\
\hline
\end{tabular}

Table IV. Strength of agreement for cephalometric measurements determined by Cohen's Kappa.

\begin{tabular}{llccccc}
\hline Variable & Analysis & Matches & Percentage & Kappa & Agreement & Kendall \\
\hline \multirow{2}{*}{ Upper incisor position } & Steiner vs Ricketts & 112 & $43.1 \%$ & 0.12 & Slight & 0.71 \\
& Steiner vs McNamara & 178 & $68.5 \%$ & 0.41 & Moderate & 0.78 \\
& Ricketts vs McNamara & 148 & $56.9 \%$ & 0.27 & Fair & 0.75 \\
\multirow{3}{*}{ Upper Incis or Inclination } & Schwartz vs Steiner & 185 & $71.2 \%$ & 0.54 & Moderate & 0.84 \\
& Schwartz vs Ricketts & 139 & $53.5 \%$ & 0.27 & Fair & 0.74 \\
& Schwartz vs Jarabak & 124 & $47.7 \%$ & 0.23 & Fair & 0.77 \\
& Schwartz vs Riedel & 123 & $47.3 \%$ & 0.27 & Fair & 0.79 \\
Lower Incisor Inclination & Tweed vs Ricketts & 182 & $70.0 \%$ & 0.48 & Moderate & 0.82 \\
& Tweed vs Downs & 164 & $63.1 \%$ & 0.34 & Fair & 0.80
\end{tabular}

authors for other cephalometric variables. For example, Qamaruddin et al. (2018) compared the cephalometric values of the ANB angle, Wits, Beta angle, W angle, and Yen angle in 2017. They employed an analysis of the variance (ANOVA) and found a statistical difference among all measured values of the skeletal classes determined by different analyses $(\mathrm{p}<0.001)$. They also found that all the analyses were equally reliable for the diagnosis of skeletal classes since a statistically significant correlation was found between skeletal classes and all sagittal cephalometric analyses performed. In contrast to Qamaruddin et al., this work showed agreement in the diagnostic results of the cephalometric measurements but not their numerical values.

A study by Burgos (2016) evaluated 127 lateral cephalograms and obtained a moderate agreement between the ANB angle, the Witts, and the USP projection. Acuña Diaz \& Chávez Sevillano (2011) reported slight agreement between the ANB angle and the USP projection. In another study, Pereda Santos (2013) obtained a moderate agreement between the ANB angle and the USP projection. Marín Cas- taño \& Arango (2000) studied 15 patients and compared the Steiner and Sassouni analyzes for the diagnosis of skeletal class. They found that the two methods were discordant in their results; nevertheless, the results were not statistically significant because the sample number of his work was reduced. Thus, their conclusions may not be representative.

In 2017, Herreros del Pozo et al. evaluated the agreement among different cephalometric measurements. They related the skeletal class values defined by Ricketts, Steiner, and McNamara as well as the agreement among Jarabak's facial biotype values with the Steiner and Ricketts approach. This paper reported a slight agreement in both skeletal and facial biotype classes. However, cephalometric analyses have a higher strength of agreement with Steiner and Ricketts.

A study by Ahmed et al. (2018) assessed the strength of agreement among cephalometric measurements for determining the maxillo-mandibular sagittal relationship. They used a similar methodology than used in the present 
study, performing kappa analyses to compare results of 161 lateral radiographs, finding a substantial strength of agreement among the different analyses.

\section{CONCLUSIONS}

According to the Kappa values obtained from the statistical analysis performed, the results showed slight to moderate diagnostic agreement among the cephalometric measurements used to determine the sagittal position and the inclination of the upper and lower incisors. These findings indicate that the results obtained from the same patient may vary as a function of the cephalometric measurement approach. However, there was a slightly better agreement among cephalometric measurements when they were analyzed for each possible diagnostic outcome, and when were analyzed by pairs. This study included a sufficient number of subjects to make the findings conclusive.

Obtaining different diagnoses when performing more than one cephalometric analysis for the determination of the same variable to be measured can be confusing. However, all cephalometric analyses performed here seem to have the same diagnostic importance and reliability. Thus, they can be used as alternative analyses to each other when specific factors make it challenging to use a single analysis. This approach can allow specialists to consider alternative cephalometric measurements, when planning orthodontic treatment, leading to a more reliable decision of performing treatment with, or without, dental extractions.

\section{ACKNOWLEDGMENTS}

This work was supported by The Mexican Council for Science and Technology (CONACYT) by the scholarship 786888 granted to IPG.

GÓMEZ-MEDINA，I. P.; AGUILAR-PÉREZ，D. A.; COLOMÉ-RUÍZ, G. E.; ZÚÑIGA-HERRERA, I. D.; ESCOFFIÉ-RAMÍREZ, M.; HERRERA-ATOCHE, J. R.; RODRÍGUEZ-CHÁVEZ, J. A. \& AGUILAR-PÉREZ, F. J. Evaluación de la concordancia diagnóstica entre mediciones cefalométricas para la determinación de la posición e inclinación de los incisivos. Int. J. Morphol., 38(5):1386-1391, 2020.

RESUMEN: Los incisivos son un factor clave en la oclusión dental y la estética dentofacial; por lo tanto, la posición sagital y la inclinación de los incisivos es un parámetro clave en el diagnóstico y la planificación del tratamiento de ortodoncia. En algunos casos, el ortodoncista utilizará más de un análisis cefalométrico y, por lo tanto, se pueden obtener resultados diferentes. El objetivo de este estudio fue establecer el acuerdo de diagnóstico entre las diferentes mediciones cefalométricas utilizadas para determinar la posición anteroposterior y la inclinación de los incisivos. Se midieron radiografías cefalométricas laterales de pacientes entre 18 y 59 años $(n=260)$. Las mediciones cefalométricas digitales se realizaron con el software Dolphin Imaging, por un solo operador calibrado. Aquí, se diseñó un análisis cefalométrico específico en el editor de análisis de software. Los resultados para cada variable y cada medición se registraron y compararon. Las pruebas estadísticas Kappa de Fleiss, Kappa de Cohen y el coeficiente de Kendall se usaron para determinar la fuerza del acuerdo utilizando el software Minitab. Los resultados mostraron un acuerdo de fuerza diagnóstica entre leve y moderado entre las mediciones de la misma variable. Esto indica que no se puede obtener el mismo diagnóstico cuando se utilizan diferentes enfoques para medir la posición anteroposterior y la inclinación de los incisivos. Se concluyó que existe una diferencia en el diagnóstico entre una medición y otra porque los resultados mostraron una fuerza de acuerdo leve o moderada. Sin embargo, en algunos casos, se encontró un mejor acuerdo cuando se compararon las mediciones en función de la respuesta de diagnóstico.

PALABRAS CLAVE: Cefalometría; Ortodoncia; Diagnóstico.

\section{REFERENCES}

Acuña Diaz, E. C. \& Chávez Sevillano, M. G. Estudio comparativo de los cefalogramas de Kim, Steiner y proyección USP en la determinación de la relación esquelética sagital. Odontol. Sanmarquina, 14(2):6-9, 2011.

Ahmed, M.; Shaikh, A. \& Fida, M. Diagnostic validity of different cephalometric analyses for assessment of the sagittal skeletal pattern. Dental Press J. Orthod., 23(5):75-81, 2018.

Burgos, S. Concordancia Cefalométrica entre el Ángulo ANB, Análisis de Wits y la Proyección USP en el Diagnóstico de la Relación entre Bases Maxilares. Tesis para Optar al Título Profesional de Cirujano Dentista. Trujillo, Universidad Privada Antenor Orrego, Facultad de Medicina Humana, Escuela Profesional de Estomatología, 2016. Available from: http://repositorio.upao.edu.pe/bitstream/ $\begin{array}{llllllllllllllll}\mathrm{u} & \mathrm{p} & \mathrm{a} & \mathrm{o} & \mathrm{r} & \mathrm{e} & \mathrm{p} & / & 2 & 0 & 1 & 6 & / & 1 & /\end{array}$ RE_ESTO_STEPHANY.BURGOS_CONCORDANCIA. CEFALOMETRICA.ANGULO \%20ANB_DATOS.PDF

Casado, A. C. Valores Cefalométricos en Población Adulta Ideal Española Tipo Facial. Tesis. Madrid, Universidad Complutense de Madrid, Facultad de Odontología, Departamento de Profilaxis, Odontopediatría y Ortodoncia, 2002. Available from: http:// webs.ucm.es/BUCM/tesis//19911996/D/0/AD0044801.pdf

de Sena, L. M. F.; de Sena, P. P. M. \& Pereira, H. S. G. Cephalometric analysis: Orthodontists versus oral radiologists. J. World Fed. Orthod., 5(1):18-21, 2016

Devereux, L.; Moles, D.; Cunningham, S. J. \& McKnight, M. How important are lateral cephalometric radiographs in orthodontic treatment planning? Am. J. Orthod. Dentofacial Orthop., 139(2):e175-e181, 2011.

Durão, A. P. R.; Morosolli, A.; Pittayapat, P.; Bolstad, N.; Ferreira, A. P. \& Jacobs, R. Cephalometric landmark variability among orthodontists and dentomaxillofacial radiologists: a comparative study. Imaging Sci. Dent., 45(4):213-20, 2015. 
Durão, A. R.; Pittayapat, P.; Rockenbach, M. I. B.; Olszewski, R.; Ng, S.; Ferreira, A. P. \& Jacobs, R. Validity of 2D lateral cephalometry in orthodontics: a systematic review. Prog. Orthod., 14(1):31, 2013.

Guerrero, M.; Ocampo, J. \& Olate, S. Comparison between Ricketts and McNamara techniques for the determination of the maxilla and mandible position in Ecuadorian youths. Int. J. Morphol., 36(1):169$74,2018$.

Gul-e-Erum \& Fida, M. A comparison of cephalometric analyses for assessing sagittal jaw relationship. J. Coll. Physicians Surg. Pak., 18(11):679-83, 2008.

Herreros del Pozo, A.; Jiménez Varo, I.; Clérigues, M. D.; Nieto Sánchez, I. \& Aneiros Fernández, L. Concordancia entre clase esquelética y biotipo facial entre diferentes análisis cefalométricos. Rev. Esp. Ortod., 47(3):146-51, 2017.

Jabbal, A.; Cobourne, M.; Donaldson, N. \& Bister, D. Assessing lower incisor inclination change: a comparison of four cephalometric methods. Eur. J. Orthod., 38(2):184-9, 2016.

Landis, J. R. \& Koch, G. G. The measurement of observer agreement for categorical data. Biometrics, 33(1):159-74, 1977.

Marín Castaño, J. F. \& Arango, I. Cefalometria Comparación y Análisis de Dos Métodos: Steiner y Sassouni. Trabajo de Cuarto Año. Santafé de Bogotá, Universidad de la Sabana, Facultad de Medicina, Especialización en Imágenes Diagnósticas Clínicas, 2000. Available from: https://intellectum.unisabana.edu.co/bitstream/handle/10818/4839/ 130414.pdf?sequence $=1$ \&isAllowed $=\mathrm{y}$

Naragond, A.; Kenganal, S.; Sagarkar, R.; Kumar, S. \& Sugaradday. Diagnostic limitations of cephalometrics in orthodontics-A review. IOSR J. Dent. Med. Sci., 3(1):30-5, 2012.

Nielsen, I. L. Cephalometric morphological analysis: what information does it give you? Int. Orthod., 9(3):316-24, 2011.

Pereda Santos, G. M. Prevalencia de Clase Esquelética según Proyección de la Universidad de São Paulo y Concordancia con Análisis según Steiner de un Grupo de Adolescentes en Trujillo - 2011. Tesis para Optar al Grado de Bachiller en Estomatología. Trujillo, Universidad Nacional de Trujillo, Facultad de Medicina, Escuela de Estomatología, 2013. Available from: http://dspace.unitru.edu.pe/bitstream/handle/ UNITRU/595/PeredaSantos_G.pdf?sequence=1\&isAllowed=y

Pittayapat, P.; Limchaichana-Bolstad, N.; Willems, G. \& Jacobs, R. Threedimensional cephalometric analysis in orthodontics: a systematic review. Orthod. Craniofac. Res., 17(2):69-91, 2014.

Qamaruddin, I.; Alam, M. K.; Shahid, F.; Tanveer, S.; Umer, M. \& Amin, E. Comparison of popular sagittal cephalometric analyses for validity and reliability. Saudi Dent. J., 30(1):43-6, 2018.

Zamora, N.; Cibrián, R.; Gandia, J. L. \& Paredes, V. Study between anb angle and wits appraisal in cone beam computed tomography (CBCT). Med. Oral Patol. Oral Cir. Bucal, 18(4):e725-e732, 2013.

\author{
Corresponding author: \\ Fernando Javier Aguilar Pérez \\ Universidad Autónoma de Yucatán \\ Facultad de Odontología \\ Calle 61-A No. 492-A Colonia Centro \\ C.P. 97000 \\ Mérida \\ Yucatán \\ MÉXICO
}

Email: fernando.aguilar@correo.uady.mx

Received: 15-05-2020

Accepted: 10-06-2020 